\title{
CZAS OCHRONY AUTORSKICH PRAW MAJAৃTKOWYCH DO UTWORU JAKO PRZEDMIOTU PRAWA AUTORSKIEGO
}

\section{Uwagi ogólne}

Przedmiotem prawa autorskiego jest utwór. Stanowi on dobro prawne niematerialne, które powinno być odróżniane od przedmiotu materialnego (corpus mechanicum), na którym utwór został utrwalony ${ }^{1}$. Przedstawiciele doktryny wskazują cechy, których łączne występowanie pozwala na wyróżnienie utworu od innych efektów działalności człowieka i uznanie wytworu niematerialnego za utwór w rozumieniu prawa autorskiego. Zagadnieniem wywołującym najwięcej kontrowersji zarówno w doktrynie, jak i w judykaturze, jest przesłanka twórczości. Problematyka twórczości ma niezwykle istotne znaczenie praktyczne. Kwestie związane z działalnością twórczą o indywidualnym charakterze są jednym z pierwszych ustaleń sądu w postępowaniu z tytułu naruszenia praw autorskich, w którym sędzia powinien rozstrzygnąć, czy mamy do czynienia z przedmiotem prawa autorskiego podlegającego ochronie autorskoprawnej. Zakres spraw rozstrzyganych przez Sąd Najwyższy dotyczył między innymi: opracowania pod względem kolorystycznym albumu składającego się z wielu litografii jako całości, charakteryzującej się określoną koncepcją plastyczną; dzieł technicznych będących rezultatem uzyskiwanym w ramach działalności zawodowej autora ${ }^{3}$; nagrobka mającego cechy artystyczne przejawiające się w inwencji twórczej, samodzielności i oryginalności opracowania ${ }^{4}$.

W niniejszym artykule został podjęty problem utworu jako przedmiotu prawa autorskiego i czasu ochrony autorskich praw majatkowych do dzieła w oparciu o dwa modele prawa autorskiego: monistyczny, przyjęty m.in. w Niemczech i Au-

\footnotetext{
J. Barta, R. Markiewicz, (w:) J. Barta, M. Czajkowska-Dąbrowska, Z. Ćwiąkalski, R. Markiewicz, E. Traple, Prawo autorskie i prawa pokrewne. Komentarz, Kraków 2005, s. 66.

Wyrok SN z 25 VIII 1972 r., II CR 261/72, OSNC 1973, nr 6, poz. 105.

Wyrok SN z 30 VI 1005 r., IV CK 763/04, OSNC 2006, nr 5, poz. 92.

Wyrok SN z 5 III 1971 r., II CR 686/70, OSNC 1971, nr 12, poz. 213.
} 
strii oraz dualistyczny, stanowiący podstawę między innymi dla prawa polskiego, francuskiego, włoskiego i hiszpańskiego.

\section{Modele prawa autorskiego}

Podstawą dla wykształcenia modeli - monistycznego i dualistycznego ${ }^{5}$ były odpowiednio teoria prawa autorskiego jako prawa osobistego (die Theorie vom Persönlichkeitsrecht) oraz teoria prawa autorskiego jako prawa na dobrach niematerialnych (die Theorie vom Immaterialgüterrecht) ${ }^{6}$.

Teoria prawa autorskiego jako prawa osobistego czy prawa osobistości rozwinęła się w Niemczech w drugiej połowie XIX w. przede wszystkim w oparciu o poglądy O.F. von Gierke. Cechą charakterystyczną tej koncepcji było ścisłe powiązanie utworu jako rezultatu wytworu intelektualnego człowieka z jego osobowością oraz wywodzenie ochrony autorskoprawnej z faktu przynależności dzieła do sfery osobowości autora. Nie negowano przy tym istnienia elementów majątkowych w prawie autorskim. Przypisywano im jednak znaczenie drugorzędne i podporządkowywano je interesom niemajątkowym. Podstawą dla wykształcenia się teorii prawa autorskiego jako prawa osobistego były idee przedstawione przez I. Kanta, który rozróżnił w „Metafizycznych podstawach nauki prawa” opus mechanicum utworu i powstające na nim prawo własności oraz treść dzieła ${ }^{7}$. Kontynuatorami myśli I. Kanta byli J.C. Bluntschli ${ }^{8}$, G. Beseler, M. Lange oraz w szczególności F. Dahn", który określił istotę prawa autorskiego jako prawo w najwyższym stopniu osobiste, którego istotą jest istnienie osobistego powiązania (vinculum spirituale). Tak rozumiane prawo autorskie jest nieprzenoszalne i niedziedziczne ${ }^{10}$. Stanowisko to zostało następnie rozwinięte w rozważaniach C. Gareisa, który uznawał, że sztuka jako taka jest bezpośrednim wyrazem osobowości twórcy. Najwyżej docenianym dążeniem człowieka do uznania jego osobowości jest chęć uznania i przyznania ochrony efektom jego świadczeń o indywidualnym, autentycznym charakterze. Wszyst-

Na zasadność wyodrębnienia modelu monistycznego i dualistycznego we współczesnych koncepcjach prawa autorskiego wskazują przedstawiciele doktryny, m.in. A. Kopff, Dzieło sztuk plastycznych i jego twórca w świetle przepisów prawa autorskiego, Kraków 1961, s. 108 i n.; E. Traple, Dzieło zależne jako przedmiot prawa autorskiego, Warszawa 1979, s. 81; E. Wojnicka, Ochrona autorskich dóbr osobistych, Łódź 1997, s. 68-70; J. Barta, R. Markiewicz, Prawo autorskie, Warszawa 2008, s. 21; M. Poźniak-Niedzielska, (w:) Prawo autorskie i prawa pokrewne. Zarys wykładu, red. M. Poźniak-Niedzielska, Bydgoszcz-Warszawa-Lublin 2007, s. 45; E. Traple, (w:) System Prawa Prywatnego. Prawo autorskie. t. 13, red. J. Barta, Warszawa 2007, s. 117-118.

6 A. Niżankowska, Prawo do integralności utworu, Warszawa 2007, s. 44.

7 I. Kant, Metafizyczne podstawy nauki prawa, Kęty 2006, s. 99-100.

8 J.C. Bluntschli, Deutsches Privatrecht, München 1864, s. 191 i n.

9 F. Dahn, Deutsches Rechtsbuch. Ein Spiegel des heutigen bürgerlichen Rechts in Deutschland, Nürdlingen 1877, s. $112-113$.

10 J.C. Bluntschli, op.cit., s. 113. Por. M. Rehbinder, Urheberrecht, München 2008, s. 14; M. Rehbinder, J.C. Bluntschlis Beitrag zur Theorie des Urheberrechts, „Archiv für Urheber- und Medienrecht” 1993, nr 123, s. $29-51$. 
kie rezultaty indywidualnych świadczeń twórcy opierają się na indywiduum osoby twórcy ${ }^{11}$.

Powyższe poglądy przedstawicieli literatury zostały rozwinięte i znalazły pełny wyraz w przemyśleniach niemieckiego prawnika i historyka prawa O.F. von Gierke. Opublikowane przez niego w pierwszym tomie „Deutsches Privatrecht”"12 rozważania w przedmiocie prawa autorskiego zostały uznane przez przedstawicieli doktryny za jedne z najistotniejszych dla wykształcenia się teorii prawa autorskiego jako prawa osobistego ${ }^{13}$. Koncepcje zwolenników teorii prawa autorskiego jako prawa osobistości stały się podstawą dla wykształcenia w XX w., głównie przez E. Ulme$\mathrm{ra}^{14} \mathrm{i}$ H. Hubmanna, ${ }^{15}$ monistycznej koncepcji prawa autorskiego. Wyróżnia się ona pewnymi cechami charakterystycznymi.

Po pierwsze, zgodnie z monistycznym modelem prawo autorskie jest ukształtowane jako prawo jednolite, obejmujące zarówno elementy majątkowe, jak i osobi$\mathrm{ste}^{16}$. Uprawnienia o charakterze osobistym i majątkowym pozostają ze sobą w ścisłym związku i tworzą nierozdzielną całość. Prawo autorskie nie jest zatem ani prawem o charakterze osobistym, ani majątkowym; jest prawem o charakterze mieszanym (Mischform $)^{17}$. Prawo autorskie spełnia zatem dwie zasadnicze funkcje, tzn. chroni interesy majątkowe i jednocześnie osobiste autora. Istotę modelu monistycznego wyjaśnił obrazowo E. Ulmer, porównując prawo autorskie do drzewa (Baumtheorie). Składające się na prawo autorskie uprawnienia o charakterze osobistym i majątkowym są w tym ujęciu porównywane do konarów i gałęzi, które niejako swoją siłę czerpią ze wspólnego korzenia - prawa autorskiego ${ }^{18}$. Twórca, wykonując prawo autorskie do swojego utworu, realizuje zarówno majątkowe, jak i niemajątkowe interesy.

Po drugie, jedność prawa autorskiego widoczna jest w zakresie czynności mortis causa mających za przedmiot prawo autorskie. Uprawnienia o charakterze osobistym powstają jednocześnie z uprawnieniami o charakterze majątkowym, są ograniczone w czasie - wraz z nimi wygasają i są dziedziczne.

11 K. Gareis, Das juristische Wesen der Autorrecht, sowie des Firmen- und Markenschutzes, „Archiv für Theorie und Praxis des Allgemeinen Deutschen Handel- und Wechselrechts” 1877, t. 35, s. 197-198.

O.F. von Gierke, Deutsches Privatrecht, Leipzig 1895, s. 748-848.

13 Zob. H. Schack, Urheber und Urhebervertragsrecht, Tübingen 2005, s. 53; M. Rehbinder, Urheberrecht..., s. 1314.

14 E. Ulmer, Urheber- und Verlagsrecht, Berlin-Heidelberg-New York 1980, s. 114 i n.

15 H. Hubmann, Urheber- und Verlagsrecht, München 1995, § 3. Por. także H. Hubmann, Das Persönlichkeitsrecht, Köln-Graz 1967, s. 233-240.

16 Z. Lendvai, Die Realisierung der Urheberpersönlichkeitsrechte in Deutschland und England, München 2003, s. $17-18$.

17 M. Rehbinder, Urheberrecht..., s. 16.

18 E. Ulmer, op. cit., s. 114 i n.. Por. H.P. Götting, (w:) H.P. Götting, C. Schertz, W. Seitz, Handbuch des Persönlichkeitsrechts, München 2008, s. 285; M. Rehbinder, Urheberrecht..., s. 16. 
Po trzecie, powiązanie autorskich uprawnień o charakterze osobistym i majątkowym w teorii monistycznej inaczej przedstawia się w odniesieniu do problematyki przenoszalności tych praw. Twórca może dowolnie rozporządzać autorskimi uprawnieniami o charakterze majątkowym. Z uwagi jednak na naturę prawa autorskiego w ujęciu monistycznym przyjmuje się, że rozporządzalność uprawnieniami o charakterze majątkowym nie obejmuje samej istoty (rdzenia) prawa autorskiego (Mutterrecht). Rdzeń prawa autorskiego rozumiany jest jako źródło zarówno uprawnień o charakterze majątkowym, jak i osobistym. W takim ujęciu rozporządzanie autorskimi uprawnieniami o charakterze majattkowym nie przybiera postaci translatywnego nabycia prawa, lecz polega na konstytutywnym obciążeniu prawa, udzieleniu licencji ${ }^{19}$. W przeciwieństwie do tego autorskie uprawnienia o charakterze osobistym nie mogą być przedmiotem rozporządzalności.

Teoria prawa autorskiego jako prawa na dobrach niematerialnych (die Theorie vom Immaterialgüterrecht) rozwijała się równolegle do teorii prawa autorskiego jako prawa osobistego ${ }^{20}$. Kształtowała się przede wszystkim w oparciu o poglądy J.G. Fichtego ${ }^{21}$, G.W.F. Hegla ${ }^{22}$ oraz A. Schopenhauera ${ }^{23}$. Wspólne dla przedstawicieli koncepcji prawa autorskiego jako prawa na dobrach niematerialnych było przekonanie, że prawo autorskie nie jest wyłącznie ani prawem majątkowym, ani osobistym $^{24}$. J.G. Fichte, podobnie jak I. Kant, rozróżniał corpus mechanicum książki oraz jego duchową zawartość, dokonując przy tym dodatkowego podziału na formę i treść dzieła. Tak oddzielona forma pozostawała nieprzenoszalną i wyłączną własnością autora, podczas gdy treść utworu z chwilą jego publikacji przestawała należeć do twórcy ${ }^{25}$. Największe znaczenie jednak dla rozróżnienia własności na rzeczy oraz własności intelektualnej miały rozważania A. Schopenhauera. W jego ocenie dzieło umysłowe (duchowe) jest własnością autora. W odróżnieniu jednak od własności materialnej, w przypadku dzieła pochodzącego od twórcy mamy do czynienia z własnością o charakterze duchowym, niematerialnym ${ }^{26}$.

W oparciu o przedstawione wyżej poglądy J. Kohler zaprezentował teorię prawa autorskiego jako prawa na dobrach niematerialnych. Opublikowane w $1880 \mathrm{r}$. rozważania w przedmiocie prawa autorskiego ${ }^{27}$ uważane są wśród przedstawicieli doktryny za podstawowe dla późniejszego wykształcenia dualistycznej koncep-

19 M. Rehbinder, Urheberrecht..., s. 16.

20 A. Niżankowska, op. cit., s. 36.

21 J.G. Fichte, Beweis der Unrechtmäßigkeit des Büchernachdrucks Ein Räsonnement und eine Parabel, „Berlinische Monatschrift" 1793, s. 443-482.

J. Frauenstädt (red.), Aus Arthur Schopenhauers handschriftlichem Nachlaß. Abhandlungen, Anmerkungen, Aphorismen und Fragmente, Leipzig 1864, s. 380 i n.

24 M. Rehbinder, Urheberrecht..., s. 14.

25 J.G. Fichte, op. cit., s. 447.

26 J. Frauenstädt, op. cit., s. 380.

27 J. Kohler, Das Autorrecht: eine zivilistische Abhandlung; zugleich ein Beitrag zur Lehre vom Eigenthum, vom Miteigenthum, vom Rechtsgeschäft und vom Individualrecht, Jena 1880. 
cji prawa autorskiego ${ }^{28}$. Zgodnie $\mathrm{z}$ jego poglądami przedmiot prawa autorskiego jest różny od przedmiotu materialnego, dlatego należy odrzucić koncepcję prawa autorskiego jako prawa własności intelektualnej. W ocenie Kohlera prawo autorskie było prawem o charakterze majątkowym (prawem przenoszalnym i zbywalnym), zaś prawa osobiste klasyfikował jako znajdujące się obok prawa autorskiego jako coś odrębnego, istniejącego poza prawem autorskim ${ }^{29}$. Teoria prawa autorskiego jako prawa na dobrach niematerialnych stała się podstawą dla wykształcenia dualistycznej koncepcji prawa autorskiego. Jej istota sprowadza się do przeprowadzenia dychotomicznego podziału pomiędzy autorskimi prawami majątkowymi i osobistymi. Można wskazać następujące cechy charakterystyczne modelu dualistycznego.

Po pierwsze, prawo autorskie w ujęciu dualistycznym składa się z dwóch odrębnych, niezależnych praw, mianowicie autorskiego prawa osobistego i autorskiego prawa majątkowego, których odrębność wynika $z$ ich natury ${ }^{30}$. Prawa majątkowe zabezpieczają korzystanie z ekonomicznej eksploatacji dzieła, zaś prawa niemajątkowe chronią osobisty stosunek twórcy do utworu ${ }^{31}$. Są one wzajemnie niezależne i posiadają odrębny byt prawny. Istnieje ponadto konieczność wprowadzenia osobnych środków ochrony dla praw osobistych i majątkowych ${ }^{32}$.

Po drugie, prawa o charakterze majątkowym są prawami przenoszalnymi i ograniczonymi w czasie. Dopuszczalne jest ich zrzeczenie się oraz pod pewnymi warunkami podlegają egzekucji. Prawa osobiste są z kolei prawami nieprzenoszalnymi i nieograniczonymi w czasie, ściśle związanymi z osobowością twórcy, chroniącymi jego osobowość - niematerialne interesy ${ }^{33}$. W konsekwencji niemożliwe jest łączne dysponowanie uprawnieniami o charakterze majątkowym i osobistym ${ }^{34}$.

\section{Utwór jako przedmiot prawa autorskiego}

Jednym z zasadniczych problemów występujących na gruncie prawa autorskiego jest określenie koniecznych cech przedmiotu ochrony, tzn. utworu. Zgodnie $\mathrm{z}$ art. 1 ust. 1 pr. aut. przedmiotem prawa autorskiego jest każdy przejaw działalności twórczej o indywidualnym charakterze, ustalony w jakiejkolwiek postaci, nieza-

\footnotetext{
28 M. Rehbinder, Urheberrecht..., s. 15; H. Hubmann, Das Persönlichkeitsrecht..., s. 234; M. Vogel, (w:) G. Schricker, Urheberrecht. Kommentar, München 2006, s. 41; H. Schack, op. cit., s. 53.

29 J. Kohler, Urheberrecht an Schriftwerken und Verlagsrecht, Stuttgart 1907, s. 128 i n.

30 M. Poźniak-Niedzielska, (w:) Prawo autorskie i prawa pokrewne..., s. 45.

31 E. Wojnicka, op. cit., s. 68-69.

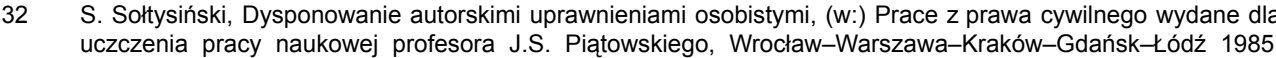
s. 41; J. Barta, R. Markiewicz, Ochrona dóbr osobistych w zakresie twórczości naukowej i artystycznej, (w:) Dobra osobiste i ich ochrona w polskim prawie cywilnym, Wrocław-Warszawa-Kraków-Gdańsk-Łódź 1986, s. 140 .

33 E. Traple, op. cit., s. 118; E. Wojnicka, op. cit., s. 69.

34 S. Sołtysiński, op. cit., s. 42.
} 
leżnie od wartości, przeznaczenia i sposobu wyrażenia. Przyjmuje się, że zgodnie z zasadą numerus clausus znajdującą zastosowanie w odniesieniu do dóbr niematerialnych, prawa majątkowe powstają wyłącznie w odniesieniu do wskazanych przez ustawodawcę rezultatów pracy intelektualnej ${ }^{35}$. Na gruncie doktryny panuje zgodne przekonanie, że dla uznania wytworu niematerialnego za utwór konieczne jest spełnienie następujących przesłanek:

1) utwór stanowi rezultat pracy człowieka,

2) utwór jest rezultatem działalności twórczej o indywidualnym charakterze,

3) utwór powinien być ustalony w jakiejkolwiek postaci ${ }^{36}$.

Ad 1) Twórcą w rozumieniu ustawy o prawie autorskim i prawach pokrewnych może być tylko człowiek. Zatem prawo do autorstwa utworu nie przysługuje osobom prawnym czy jednostkom organizacyjnym nieposiadającym osobowości prawnej. Przedmiotem prawa autorskiego nie są twory przyrody, takie jak wzory na szybach „namalowane” przez mróz ${ }^{37}$.

Ad 2) Utwór powinien posiadać cechy oryginalności i indywidualności. Pogląd ten potwierdza Sąd Najwyższy w swoim orzecznictwie. Sąd Najwyższy w wyroku z 27 III 1965 r. ${ }^{38}$ stwierdził, że przedmiotem prawa autorskiego jest każde opracowanie literackie, w którym przejawia się twórcza praca autora, a więc gdy dzięki pomysłowości i indywidualnemu ujęciu dzieło uzyskało oryginalną postać. Stanowisko to rozwinął Sąd Najwyższy w wyroku z 15 XI 2002 r. ${ }^{39}$, uznając, że wymaganie przejawu działalności twórczej określa się często mianem oryginalności, a wymaganie indywidualnego charakteru - terminem ,indywidualność”, łącznie zaś terminem „twórczość”. Tak rozumiana twórczość jest zawsze przejawem indywidualnego ujęcia i w następstwie tego prowadzi do powstania rezultatu niepowtarzalnego i to bez względu na to, jaki jest rozmiar oryginalności rezultatu oraz jaka jest jego użyteczność lub wartość. Pogląd ten poparł Naczelny Sąd Administracyjny w wyroku z 13 $\mathrm{X} 2005 \mathrm{r}^{40}$, wskazując, że utworem w rozumieniu prawa autorskiego jest dzieło posiadające cechy oryginalności i indywidualności.

Ad 3) Ochrona autorskoprawna powstaje z chwilą ustalenia dzieła. Ustaleniem utworu jest uzewnętrznienie dzieła umożliwiające jego percepcję przez osoby trzecie, inne niż twórca. Od ustalenia należy odróżnić utrwalenie utworu, przez które należy rozumieć ,rodzaj trwałego ustalenia utworu przez wyrażenie jego treści na nośniku materialnym, umożliwiające wielokrotne odtwarzanie i percepcję tych sa-

J. Barta, R. Markiewicz, Prawo autorskie, Warszawa 2008, s. 24

Ibidem, s. 66.

J. Barta, R. Markiewicz, (w:) J. Barta i in., s. 67.

I CR 38/65, Prawo autorskie w orzecznictwie (CD-ROM), pod red. T. Grzeszak, Warszawa 1998.

II CKN 1289/00, OSNC 2004, nr 3, poz. 44.

FSK 2253/04, Lex nr 173097. 
mych treści" ${ }^{41}$. Powstanie prawa autorskiego nie jest uzależnione od zarejestrowania utworu na jakimkolwiek nośniku materialnym (utrwalenia) ${ }^{42}$.

Zgodnie z art. 4 pr. aut. nie stanowią przedmiotu prawa autorskiego:

- akty normatywne lub ich urzędowe projekty,

- urzędowe dokumenty, materiały, znaki i symbole,

- opublikowane opisy patentowe lub ochronne,

- proste informacje prasowe.

Analiza orzecznictwa sądowego prowadzi do wniosku, że ochrony autorskoprawnej sądy odmówiły przykładowo: wykazowi artykułów weterynaryjnych z normatywami ich zużycia ${ }^{43}$, instrukcji służbowej ${ }^{44}$, projektom zagospodarowania przestrzennego $\mathrm{kraju}^{45}$, pytaniom egzaminacyjnym na prawo jazdy ${ }^{46}$, opiniom i raportom $\mathrm{z}$ badania sprawozdań finansowych ${ }^{47}$.

\section{Czas ochrony autorskich praw majątkowych w ujęciu historycznym}

Autorskie prawa majątkowe są skonstruowane jako prawa ograniczone w czasie. Zasadniczą konsekwencją przyjęcia zasady czasowego ograniczenia autorskich praw majątkowych jest to, że po upływie terminu przewidzianego w ustawie każdy może swobodnie i nieodpłatnie korzystać z utworu ${ }^{48}$. Jedynym warunkiem jest konieczność poszanowania autorskich praw osobistych. Odstępstwem od wskazanej zasady jest instytucja domaine public payant, przewidująca obowiązek dokonywania zapłaty pewnych kwot na Fundusz Promocji Twórczości ${ }^{49}$. W konsekwencji upływ terminu przewidzianego przepisami prawa sprawia, że utwór staje się powszechnie dostępny i nie podlega ochronie z tytułu prawa autorskiego. Wraz z wygaśnięciem praw, każdy może utwór powielić, rozpowszechnić, wystawić czy przedstawić bez konieczności uzyskiwania zgody twórcy czy zapłaty odpowiedniej sumy pieniężnej ${ }^{50}$. Wymaga jednaj podkreślenia, że takie działanie może prowadzić do na-

\footnotetext{
41 H. Przybysz, (w:) Leksykon własności przemysłowej i intelektualnej, pod red. A. Szewca, Karków 2003, s. 276.

42 J. Barta, R. Markiewicz, Prawo autorskie..., s. 50.

43 Wyrok SN z 15 VII 1957 r., OSPiKA 1958 I CR 643/56, poz. 272.

44 Wyrok SN z 24 VI 1987 r., OSPiKA 1989 II CR 46/87, nr 1, poz. 3.

45 Wyrok SN z 25 X 1972 r., OSPiKA 1975 II PR 318/72, nr 9, poz. 203.

46 Wyrok SN z 26 IX 2001 r., IV CKN 458/00, LEX nr 52711.

47 Wyrok NSA w Lublinie z 30 VI 1999 r., I SA/Lu 407/98, Lex nr 40048.

48 J. Barta, R. Markiewicz, (w:) J. Barta i in., s. 374. Por. J. Błeszyński, Czas ochrony autorskich praw majątkowych, Państwo i Prawo 1977, nr 2, s. 61 i n.

49 E. Traple (w:) System Prawa Prywatnego. Prawo autorskie, t. 13, pod red. J. Barty, Warszawa 2007, s. 201. Szerzej na temat instytucji domaine public payant patrz A. Kopff, Domaine public payant, ZNUJ PWiOWI 1992, nr 58.

Por. M. Rehbinder, Urheberrecht, München 2008, s. 195.
} 
ruszenia dóbr osobistych wymienionych w art. 23 kc., a zwłaszcza twórczości artystycznej.

Czasowe ograniczenie autorskich praw majątkowych oznacza wygaśnięcie samego prawa wraz z upływem terminu przewidzianego w ustawie, nie zaś - jak podnoszą niektórzy przedstawiciele doktryny - wygaśnięcie ochrony przyznanej przez przepisy prawa autorskiego. Jak zauważa J. Błeszyński, koncepcja ta byłaby jednak sprzeczna z konstrukcją praw podmiotowych i dlatego przyjmuje się wygaśnięcie autorskich praw majątkowych ${ }^{51}$. Autorskie prawa majątkowe nie ulegają przedawnieniu. Od wygaśnięcia praw należy bowiem odróżnić przedawnienie konkretnych roszczeń wynikających z tych praw ${ }^{52}$. Aby można było dochodzić roszczeń z tytułu naruszenia autorskich praw majątkowych, działanie naruszające powinno nastąpić przed upływem okresu ochrony ${ }^{53}$.

Unormowania przewidujące ograniczony czas trwania autorskich praw majątkowych odnoszą się do prawa autorskiego bezwzględnego. W związku z tym dotyczą również następców prawnych podmiotu praw autorskich. Zdaniem J. Błeszyńskiego odwołanie do ogólnych zasad prawa cywilnego pozwala w szczególności nawiązać do zasady nemo plus iuris ad alium transfere potest quam ipse habet. W konsekwencji, z upływem terminu wskazanego w ustawie, można nieodpłatnie korzystać z dzieła bez konieczności uzyskiwania zezwolenia niezależnie od tego, komu przysługują autorskie prawa majątkowe do utworu ${ }^{54}$.

Ustawa o prawie autorskim i prawach pokrewnych przewiduje siedemdziesięcioletni okres trwania autorskich praw majątkowych, liczony co do zasady od śmierci twórcy. Autorskie prawa majątkowe trwają od chwili stworzenia dzieła przez całe życie twórcy oraz czas siedemdziesięciu lat po jego śmierci. Okres ten nie może zostać przedłużony lub skrócony przez czynność prawną ${ }^{55}$. Czas ochrony autorskich praw majątkowych liczy się w latach pełnych następujących po roku, w którym nastąpiło zdarzenie, od którego rozpoczyna się bieg terminów (art. 39 pr. aut.). Zgodnie $\mathrm{z}$ art. 36 pr. aut. autorskie prawa majątkowe gasną $\mathrm{z}$ upływem lat siedemdziesięciu:

1) od śmierci twórcy, a do utworów współautorskich - od śmierci współtwórcy, który przeżył pozostałych;

\footnotetext{
51 J. Błeszyński, Prawo autorskie, Warszawa 1985, s. 163.

52 Ibidem, s. 170.

53 J. Barta, R. Markiewicz (w:) J. Barta, M. Czajkowska-Dąbrowska, Z. Ćwiąkalski, R. Markiewicz, E. Traple, Prawo autorskie i prawa pokrewne. Komentarz, Kraków 2005, s.374.

54 J. Błeszyński, op. cit., s. 168.

55 J. Barta, R. Markiewicz, (w:) J. Barta, M. Czajkowska-Dąbrowska, Z. Ćwiąkalski, R. Markiewicz, E. Traple, Prawo autorskie..., s. 374-375.
} 
2) w odniesieniu do utworu, którego twórca nie jest znany - od daty pierwszego rozpowszechnienia, chyba że pseudonim nie pozostawia wątpliwości co do tożsamości autora lub jeżeli autor ujawnił swoją tożsamość;

3) w odniesieniu do utworu, do którego autorskie prawa majątkowe przysługują z mocy ustawy innej osobie niż twórca - od daty rozpowszechnienia utworu, a gdy utwór nie został rozpowszechniony - od daty jego ustalenia;

4) w odniesieniu do utworu audiowizualnego - od śmierci najpóźniej zmarłej z wymienionych osób: głównego reżysera, autora scenariusza, autora dialogów, kompozytora muzyki skomponowanej do utworu audiowizualnego.

Czas ochrony autorskich praw majątkowych do utworów rozpowszechnionych w częściach odcinkach, fragmentach lub wkładkach terminu liczy się oddzielnie od daty rozpowszechnienia każdej z wymienionych części.

$\mathrm{Na}$ gruncie ustawy o prawie autorskim z $1926 \mathrm{r}$. czas ochrony autorskich praw majątkowych wynosił 50 lat. Art. 26 ustawy o prawie autorskim z 1952 r. wprowadził 25-letni czas ochrony autorskich majątkowych. Wraz z kolejnymi nowelizacjami prawa autorskiego był on systematycznie wydłużany. Z chwilą wejścia w życie obecnie obowiązującej ustawy o prawie autorskim i prawach pokrewnych wynosił 50 lat. Minimalny czas ochrony ustanowiony przez Konwencję berneńską ${ }^{56}$, obejmujący okres życia autora oraz okres 50 lat liczony od dnia jego śmierci, miał zapewnić ochronę interesów autora oraz dwóch pierwszych pokoleń jego zstępnych. Średni okres życia w krajach Unii Europejskiej wydłużył się do tego stopnia, że ustalony czas nie jest już wystarczający, aby objąć dwa pokolenia. Ponadto niektóre państwa członkowskie ustaliły we własnych ustawodawstwach okres dłuższy niż 50 lat po śmierci twórcy. Okoliczności te oraz obawa, że istniejące różnice w ramach wewnętrznych ustawodawstw państw członkowskich będą utrudniać swobodny przepływ towarów i swobodę wykonywania usług, wypaczając w ten sposób konkurencję na wspólnym rynku, przemawiały za generalnym wydłużeniem okresu ochrony praw autorskich. W konsekwencji, prawodawca unijny w dyrektywie nr 93/98/WE z dnia 29 października 1993 r. w sprawie harmonizacji czasu ochrony prawa autorskiego i niektórych praw pokrewnych ${ }^{57}$ ustanowił jednolity czas ochrony autorskich praw majątkowych w Unii Europejskiej, który obecnie wynosi 70 lat. Dyrektywa została implementowana ustawą z dnia 9 czerwca 2000 r. o zmianie ustawy o prawie autorskim i prawach pokrewnych ${ }^{58}$.

Ustawodawca w szczególny sposób unormował czas trwania autorskich praw majątkowych do dzieła współautorskiego. Zgodnie z art. 36 pkt 1 pr. aut. autorskie

\footnotetext{
56 Akt paryski konwencji berneńskiej o ochronie dzieł literackich i artystycznych, sporządzony w Paryżu z dnia 24 lipca 1971 r., Dz.U. z 1990 r. Nr 82, poz. 474, załącznik.

57 Dz.Urz. WE L 290 z 24.11.1993.

58 Dz.U. Nr 53, poz. 637.
} 
prawa majątkowe do utworu współautorskiego gasną z upływem siedemdziesięciu lat od śmierci najpóźniej zmarłego współautora. W konsekwencji utwory będące efektem współtworzenia objęte są dłuższą ochroną autorskoprawną. Przykładowo utwory Klausa Manna (18.11.1906-21.05.1949) są objęte ochroną z tytułu prawa autorskiego do 31 grudnia 2019 r. Jednakże czas ochrony utworu „The Other Germany”, napisanego wspólnie z jego siostrą Eriką (09.11.1905-27.08.1969), wygasa dopiero 31 grudnia 2039 r. z uwagi na charakterystyczny dla utworu współautorskiego sposób obliczania czasu ochrony ${ }^{59}$. Na gruncie doktryny panuje zgodny pogląd, że wskazane przepisy znajdują zastosowanie jedynie do faktycznego współautorstwa w rozumieniu art. 9 pr. aut. ${ }^{60}$. W związku z tym hipotezą przepisów normujących czas trwania autorskich praw majątkowych do dzieła współautorskiego nie zostały objęte utwory połączone, dzieła zbiorowe czy zależne. We wskazanych przypadkach czas ochrony dla każdej z samodzielnych części liczy się oddzielnie - w odniesieniu do dzieł połączonych dla każdego utworu z osobna, przy zbiorach utworów dla każdego z wkładów i utworu jako całości, w przypadku utworów zależnych osobno dla dzieła macierzystego i opracowania ${ }^{61}$.

Problematyka czasu ochrony autorskich praw majątkowych do utworu wspó1autorskiego była przedmiotem rozważań polskiej judykatury. Jednym z bardziej znanych orzeczeń w tym zakresie jest uchwała Sądu Najwyższego z 15 X 1991 r. $^{62}$, w którym SN, udzielając odpowiedzi na pytanie prawne Sądu Apelacyjnego w Warszawie, badał, z upływem jakiego okresu wygasają autorskie praw majątkowe służące autorowi utworu muzycznego stworzonego jako ilustracja muzyczna do utworu kinematograficznego. Przedstawienie stanowiska Sądu Najwyższego wymaga wskazania, że na gruncie ustawy o prawie autorskim z 1952 r. czas ochrony autorskich praw majątkowych wynoszący 25 lat doznawał wyjątku in minus w odniesieniu do utworu kinematograficznego, chronionego przez okres 10 lat $^{63}$. W ocenie Sądu samodzielny byt utworu muzycznego wykorzystanego do stworzenia dzieła łącznego nie pozwala na traktowanie go wyłącznie jako nierozłącznego jego elementu twórczego całości. Wynika to z treści art. $11 \S 2$ ustawy o prawie autorskim z $1952 \mathrm{r}$. Zgodnie z tym przepisem, twórcy dzieł łącznych mają wspólne prawo do całości, jednakże każdy z nich zachowuje równocześnie odrębne prawa autorskie do swojego dzieła. W konsekwencji w obrocie prawnym normowanym przepisami prawa autorskiego utwór muzyczny może być traktowany jako element utworu kinematograficznego, który jest samodzielnym przedmiotem prawa autorskiego, ale z powodu

A. Nordemann, (w:) W. Nordemann, T.W. Boddien, F.K. Fromm, Urheberrecht. Kommentar zum Urheberrechtsgesetz, Verlagsgesetz, Urheberrechtswahrnehmungsgesetz, Stuttgart 2008, s. 1076-1077.

60 Ibidem, s. 1076-1078.

61 Por. Th. Dreier, (w:) Th. Dreier, G. Schulze, Urheberrechtsgesetz, Urheberrechtswahrnehmungsgesetz, Kunsturhebergesetz. Kommentar, München 2006, s. 857.

$62 \quad$ III CZP 97/91, OSN 1992, nr 6, poz. 92.

63 J. Błeszyński, Czas ochrony majątkowej muzyki w filmie, (w:) Z zagadnień współczesnego prawa cywilnego. Księga poświęcona Tomaszowi Dybowskiemu, „Studia luridica” 1994, t. 21. 
swojej odrębności prawnej i zdolności do wyrażania się poza filmem może być też traktowany niezależnie od dzieła, do którego ustalenia przyczynił się. Dlatego też utwór muzyczny rozpowszechniany jako wkład w dzieło filmowe podlega ochronie autorskoprawnej przez okres 10 lat ustanowiony dla utworu kinematograficznego, a w sytuacji rozpowszechniania dzieła poza filmem albo w innych warunkach przez okres 25 lat, stosownie do art. 26 ustawy o prawie autorskim z 1952 r. ${ }^{64}$

\section{Wnioski}

Wybór teoretycznego modelu prawa autorskiego wpływa na sposób ukształtowania treści prawa autorskiego. Zasadnicze różnice pomiędzy ujęciem dualistycznym a monistycznym prawa autorskiego można wskazać w oparciu o kryteria odnoszące się do prawa podmiotowego przysługującego twórcy oraz dopuszczalności rozporządzania prawem autorskim. Cechą charakterystyczną modelu monistycznego jest traktowanie prawa autorskiego jako jednego prawa podmiotowego przysługującego twórcy, na które składają się uprawnienia osobiste i majątkowe w rozumieniu składników treści tego prawa. Tworzą one nierozdzielną całość, czego konsekwencją jest niemożność przeniesienia prawa autorskiego. W ujęciu monistycznym dopuszczalne jest jedynie udzielenie licencji, upoważnienie osoby trzeciej do wykonywania prawa autorskiego w zakresie uprawnień o charakterze majątkowym. Uprawnienia o charakterze osobistym nie mogą być przedmiotem czynności o charakterze upoważniającym. Jedność prawa autorskiego widoczna jest w zakresie czynności mortis causa mających za przedmiot prawo autorskie. Uprawnienia o charakterze osobistym powstaja jednocześnie z uprawnieniami o charakterze majątkowym, są ograniczone w czasie, wraz z nimi wygasają i są dziedziczne ${ }^{65}$.

W odróżnieniu od ujęcia monistycznego, dualistyczna konstrukcja ukształtowania treści prawa autorskiego sprowadza się do przyznania twórcy dwóch praw podmiotowych - autorskiego prawa majątkowego i autorskiego prawa osobistego. Posiadają one odrębny byt prawny. Prawa majątkowe są prawami przenoszalnymi i ograniczonymi w czasie. Ustawodawca dopuszcza możliwość przyznania z mocy prawa autorskich praw majątkowych podmiotowi innemu niż twórca. Natomiast autorskie prawa osobiste są prawami nieprzenoszalnymi i nieograniczonymi w czasie, ściśle związanymi z osobowością twórcy. Cechą wspólną obu wskazanych modeli prawa autorskiego jest okoliczność przynależności autorskich praw (uprawnień) o charakterze osobistym do twórcy.

Ustawodawca w art. 36 pr. aut. ustanowił siedemdziesięcioletni czas ochrony autorskich praw majątkowych. Jest on liczony w latach pełnych następujących po

64 Por. M. Szaciński, Glosa do uchwały SN z 15 X 1991 r., III CZP 97/91, OSP 1992, nr 9, poz. 205.

65 M. Rehbinder, Urheberrecht, München 2008, s. 196. 
roku, w którym nastapiło zdarzenie, od którego rozpoczyna się bieg terminów. Czas ochrony autorskich praw majątkowych do utworu współautorskiego odpowiada specyfice dzieła łączącego wkłady twórcze kilku osób. Z uwagi na fakt, że w procesie powstania utworu bierze udział kilku autorów wnoszących wkłady twórcze, przy obliczaniu czasu ochrony autorskich praw majątkowych należy uwzględnić okres życia wszystkich współtwórców. Postulat ten znalazł odzwierciedlenie w rozwiązaniach prawnych przyjętych w polskiej ustawie o prawie autorskim i prawach pokrewnych.

Zgodnie z generalną zasadą czas ochrony autorskoprawnej jest liczony od daty śmierci twórcy lub najpóźniej zmarłego współautora. W przypadku dzieł audiowizualnych jest liczony od śmierci najpóźniej zmarłej z wymienionych osób:

a) głównego reżysera,

b) autora scenariusza,

c) autora dialogów,

d) kompozytora muzyki skomponowanej do utworu audiowizualnego.

Czas ochrony utworów anonimowych lub opublikowanych pod pseudonimem jest liczony od daty pierwszego rozpowszechnienia, chyba że pseudonim nie pozostawia wątpliwości co do tożsamości autora lub jeżeli autor ujawnił swoją tożsamość.

W przypadku utworu, do którego autorskie prawa majątkowe przysługują z mocy ustawy osobie innej niż twórca, siedemdziesięcioletni czas ochrony autorskich praw majątkowych liczy się od daty rozpowszechnienia utworu, a gdy utwór nie został rozpowszechniony - od daty jego ustalenia. 


\title{
THE DOCTRINE'S IDEAS CONCERNING THE JOINT AUTHORSHIP AND THE PROTECTION OF COPYRIGHT IN HISTORICAL REVIEW
}

\author{
SUMMARY
}

This article refers to a very important topic concerning the subject matter of copyright protection and the duration of this protection form the historical point of view. At the beginning it is an analysis of two basic theories concerning copyright law system and its legal consequences in the field of Polish and German law. Then the authors consider the work as a subject matter of copyright, which is defined by legislator as all manifestation of creative activity of individual nature, established in any form, irrespective of its value, designation or manner of expression. Within this topic the necessary conditions to establish the author's work are represented. In this article the Authors examine the duration of copyright protection in the historical conception. The author's economic rights shall expire generally after the lapse of seventy years from the death of the author. But there are a lot of exceptions, for instance in the case of joint works- from the death of the coauthor who has survived the others or in the case of an audio-visual work - from the death of the last of the following: the main director, the author of screenplay, author of dialogues, composer of music written for the audio-visual work. 